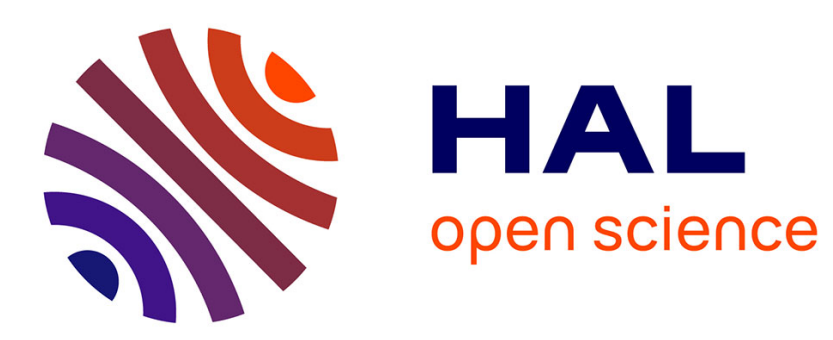

\title{
A pioneer in the development of modern ultrasound: Robert William Boyle (1883-1955)
}

\author{
Roozbeh Arshadi, Richard C. Cobbold
}

\section{To cite this version:}

Roozbeh Arshadi, Richard C. Cobbold. A pioneer in the development of modern ultrasound: Robert William Boyle (1883-1955). Ultrasound in Medicine \& Biology, 2007, 33 (1), pp.3-14. 10.1016/j.ultrasmedbio.2006.07.030 . hal-01577638

\section{HAL Id: hal-01577638 \\ https://hal.science/hal-01577638}

Submitted on 27 Aug 2017

HAL is a multi-disciplinary open access archive for the deposit and dissemination of scientific research documents, whether they are published or not. The documents may come from teaching and research institutions in France or abroad, or from public or private research centers.
L'archive ouverte pluridisciplinaire HAL, est destinée au dépôt et à la diffusion de documents scientifiques de niveau recherche, publiés ou non, émanant des établissements d'enseignement et de recherche français ou étrangers, des laboratoires publics ou privés. 


\title{
A PIONEER IN THE DEVELOPMENT OF MODERN ULTRASOUND: ROBERT W. BOYLE (1883-1955)
}

\author{
Roozbeh Arshadi and Richard S. C. Cobbold \\ Institute of Biomaterials and Biomedical Engineering, University of Toronto, Toronto, Ontario, Canada \\ (Received 29 May 2006; revised 5 July 2006; in final form 20 July 2006)
}

\begin{abstract}
Robert W. Boyle was one of the pioneers in the development and application of ultrasound. His remarkable career has not been previously traced in any depth, nor have his contributions, especially those during WWI, been carefully described. In collaboration with Lord Rutherford, his work on the development of ultrasound methods for submarine detection paralleled those in France under Paul Langevin (1872-1946), who many consider to be the father of modern ultrasound. This biographic account of Boyle's life focuses on his ultrasound research contributions, particularly the developments during WWI and those in the 10 years after. Evidence is presented that his pioneering research, along with that of Langevin, provided much of the foundation for modern ultrasound developments. Although this paper is partially based on somewhat dispersed biographic information performed by others, original letters and research papers, in addition to records and verbal accounts provided by relatives, have been used and consulted. (E-mail: cobbold@ecf.utoronto.ca) (C) 2006 World Federation for Ultrasound in Medicine \& Biology.
\end{abstract}

Key Words: History of ultrasound, Pioneer, Biography, Robert William Boyle.

\section{THE EARLY YEARS (1883-1909)}

Robert Boyle was born on October 2, 1883, in the fishing and sealing community of Carbonear, Newfoundland. Carbonear is about 60 miles from St. John's and is located on the northern coast of Conception Bay. His father, Albert Desbrissay Boyle (1857-1932), was born on Prince Edward Island and studied medicine at McGill. Upon graduating in 1877 he initially established a practice as "Physician and Surgeon," with an office and lodgings in Mr. John Foote's Hotel in Carbonear (John Foote was a sailmaker by trade, but also ran a hotel). On April 29, 1881, Albert married Sophie Maddock (18601930), eldest daughter of R. Maddock of Carbonear. They had 11 children, although not all survived to adulthood. Of the nine who survived to childhood, Robert was the first of the seven boys: Robert, George (1887-1922), Albert (1889-1958), John (1891-1896), Frederick (1893-1950), Frank (1895-1901) and Hubert (1897-1973). The boys had two sisters, Margaret Anna (1885-1982) and Mary Ellen (1892-1966). Robert received his early education at the Carbonear Grammar

Address correspondence to: Professor Richard S. C. Cobbold, Institute of Biomaterials and Biomedical Engineering, University of Toronto, Rosebrugh Bld., 164 College Street, Toronto, Ontario, M5S 3G9, Canada. E-mail: cobbold@ecf.utoronto.ca
School, where, at the age of 14 , he won the Intermediate Grade Outport Scholarship. This enabled him to attend the Old Methodist College in St. John's from which he graduated in 1900. He was awarded a Newfoundland Diamond Jubilee Scholarship established by the Newfoundland legislature in 1891. This enabled him to enroll in the Faculty of Applied Science at McGill University in 1901, where he began studies in engineering, specializing in electrical engineering.

In September 1898, at the age of 27, the future Nobel Prize winner Ernest Rutherford arrived at McGill University to assume an appointment as the second McDonald Professor of Physics (the first McDonald Professor was Hugh L. Callender, who had accepted a Chair at University College, London). Rutherford had studied under Professor J.J. Thompson at the Cavendish Laboratories in Cambridge (J.J. discovered the electron) and had already established an enviable reputation for scientific research. Over the next nine years at McGill, he made discoveries that had a profound effect on our understanding of the structure of matter. These discoveries resulted in him receiving the Nobel Prize in Chemistry, a year after he had left McGill in 1907 for the University of Victoria (Manchester, England) as a professor of physics. When Boyle arrived at McGill to study electrical engineering, it is likely that he attended lec- 
tures by Rutherford and was strongly influenced by his enthusiasm for research and his key discoveries in the field of radioactivity. According to the McGill academic calendars, Boyle had an outstanding academic record and was awarded a variety of prizes, medals and scholarships during his four-year undergraduate program. In the McGill calendar for 1905 to 1906, he is listed as having been granted the B.Sc. degree in 1905, standing first in the sessional examinations. The records also show that he was awarded the M.Sc. degree in 1906, which he may have obtained through additional advanced courses and perhaps a thesis. In addition, the records show that he was awarded a prize for his summer thesis work in 1905, suggesting that he may have performed experimental work in Rutherford's research group. For the 1905 to 1906 year, he was appointed Demonstrator in the Department of Physics and, for the 1907 to 1909 academic years, he was Senior Demonstrator in Physics and Lecturer in Mathematics. No doubt, the stipends associated with these appointments helped to finance his graduate research on radioactivity under Rutherford's guidance. The discoveries reported by Rutherford from McGill's Physics Laboratory attracted many eminent visitors (several went on to win Nobel prizes); meeting and interacting with them was probably an important experience for Boyle. As a Ph.D. candidate, Rutherford was likely the sole supervisor but, subsequently, when he left in mid1907, Boyle's thesis was listed as being under the joint supervision of John Cox, H.T. Barnes and A.S. Eve, all of whom are pictured in Fig. 1. In writing to Rutherford at Manchester on November 29, 1907 (Marsden 1956), Boyle complained about the Ph.D. language requirements, suggesting that this would add about six months to his Ph.D. studies. Moreover, he discussed possible reasons as to why he was turned down for the 1851 Exhibition Scholarship that he had applied for, probably with Rutherford's encouragement. It was in the following year that Henry Marshall Tory, a close friend of Rutherford, an Associate Professor of mathematics and an advisor to the Principal of McGill, was invited to become the founding President of the new University of Alberta. As will be seen, Tory played a major role in Boyle's future career path.

Boyle's Ph.D. thesis, entitled "Absorption and adsorption with reference to the radioactive emanations," was the first to be awarded in the Department of Physics. Although his degree was listed as having been awarded in 1909, [4] the printed version, [3] which was typeset in England, was dated 1910. His first paper, based in part on his Ph.D. studies, was published in the Journal of Physical Chemistry in 1908. This 22-page contribution described how the emissions from a radioactive medium were absorbed by charcoal.[2] In 1909, he was also

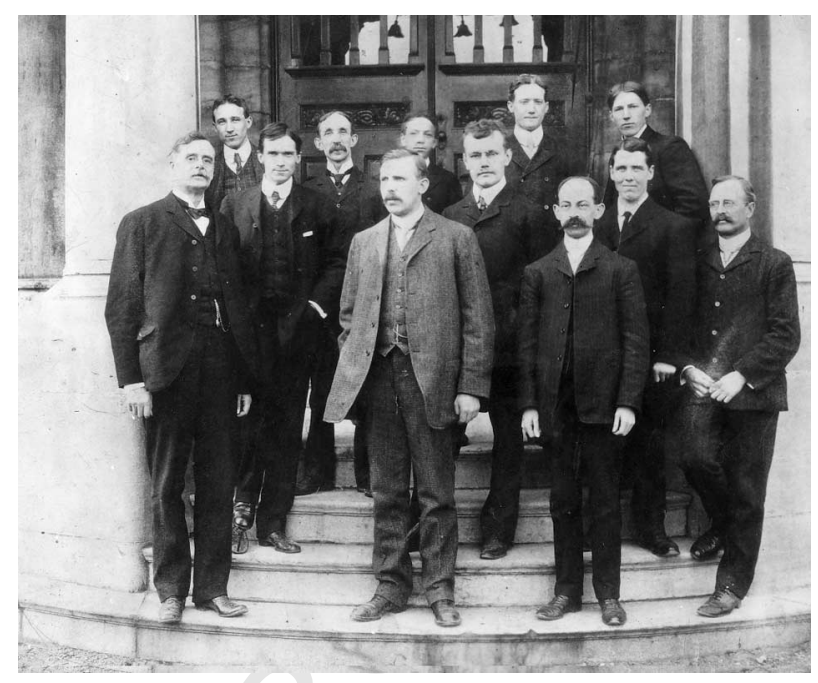

Fig. 1. McGill Physics Department staff in 1907 outside the McDonald Physics laboratory building, probably taken shortly before Rutherford left for Manchester. (Reproduced with permission of the McGill University Archives, Montreal.) Front row: J. Cox, E. Rutherford, K.R. McClung, A.S. Eve. Middle row: H.T. Barnes, O. Rumelin, H. Bronson. Top row: R.W. Boyle, L. LeGrow, S. Podville, R. Lawrence, G. Dunn.

awarded the M.A. degree, although this may have been a purely formal matter.

\section{IMMEDIATE POSTDOCTORAL YEARS (1909-1911)}

In 1909, Boyle was awarded an 1851 Exhibition Scholarship, the same scholarship that had been awarded to Rutherford when he was at Christchurch, University of New Zealand, and which had enabled him to study at the Cavendish Laboratory. It seems likely that Rutherford may have used his considerable influence to ensure that Boyle received this award, thereby enabling him to join his research group in Manchester. This group consisted of many outstanding scientists focused on understanding radioactive emissions and their effects, as well as on the development of new measurement methods. In corresponding with his old friend and colleague, Professor B.B. Boltwood of Yale University, Rutherford wrote from Manchester on July 21, 1910 (Badash 1969): “....Boyle, Grey and Wilson still remain." Again, on December 14, 1910, Rutherford wrote to Boltwood (Badash 1969): "Boyle is working on the absorption of the emanation in water, and is happy up in the attic." Later, in writing to Otto Hahn on October 2, 1911 (Eve 1939), Rutherford wrote: "Kovarik is back in America, and Boyle in Canada. I shall miss both of them." These and other references indicate the high regard that Rutherford had for Boyle.

While at Manchester, Boyle published or submitted for publication three papers in the Philosophical Maga- 


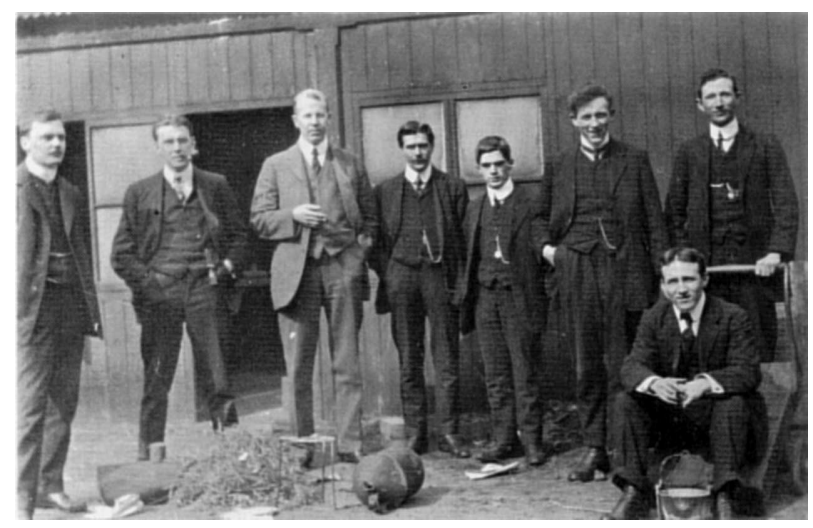

Fig. 2. Some of Rutherford's research students and visitors in front of a shed used to accommodate the overflow. Boyle can be seen seated on the far right, Hans Geiger (of Geiger counter fame) is at the far left and Boltwood, an old friend and colleague of Rutherford and a visiting professor from Yale University, is third from left. (Courtesy of the late L.V. Hammond and Yale University Press (Badash 1969).)

zine $[5,7,8]$ and one in the Transactions of the Royal Society of Canada.[6] It should be noted that these and his earlier research were mentioned several times in Rutherford's well-known book on radioactivity (Rutherford 1913), published in 1913. During his years at Manchester, Rutherford would regularly visit his "boys" and perch himself on the nearest stool to discuss their problems and recent results. It is likely that he visited Boyle in the attic of the overflow Physics shed (see Fig. 2). Subsequent correspondence (August 14, 1912) with Rutherford (Marsden 1956) revealed that, at Manchester, part of Boyle's work was with Rutherford and concerned $\gamma$-rays, but that work had to be terminated when he returned to Canada. However, he did spend time in the summer of 1912 to "classify the results on that $\gamma$-ray work with you".

\section{ACADEMIA: MCGILL AND ALBERTA (1911-1916)}

On completing the 2-y term of his scholarship, Boyle returned to McGill in 1911 to join the Physics Department, first as Lecturer and then, in the second semester, as Assistant Professor (Shaw 1955). In writing to Rutherford on August 29, 1912, Boyle states that he missed the old regime in the Physics Department under Rutherford: ". . . and the feeling of continually treading on hot bricks is not exactly comfortable and for myself I love to breathe a free atmosphere" (Marsden 1956).

In 1907, fires had destroyed much of the Engineering Building and a good part of the Medical Building, causing great financial difficulties for McGill (Eve 1939). According to Wilson (1983), Boyle engaged in extensive correspondence with Rutherford over these and other problems, as well as the possibility of accepting a Professorship in Physics in the recently established University of Alberta in Edmonton. As noted earlier, Dr. H.M. Tory had left McGill in 1908 and, as the founding President, was anxious to recruit young faculty members of ability and drive who could be expected to develop research programs along the lines of those established at McGill. Boyle eventually accepted the offer and moved to take up this new position in the late summer of 1912 .

There can be little doubt that the initial years at Edmonton must have been very challenging, with a great deal of time taken up with all the problems of establishing a new Physics Department, hiring staff and, subsequently, establishing an electrical engineering program. In spite of this, it is clear that Boyle was able to conduct some research on radioactivity, as is evident from the continuing correspondence with Rutherford. For example, on September 30, 1912, Boyle wrote to Rutherford (Marsden 1956) "about getting a little radium," which duly arrived at the end of November. Again, on April 13, 1913 (Marsden 1956), he wrote to request research information and copies of publications. In fact, as evidenced by the regular correspondence and visits throughout the years, a close scientific and personal relationship existed that continued throughout the years until shortly before Rutherford's death in 1937.

\section{DEVELOPMENT OF SONAR DURING WORLD WAR I (1916-1919)}

(Hunt's well-known book on electroacoustics (Hunt 1954) contained a full chapter on the history, including a well-researched section on the development of antisubmarine ultrasonic detection. In a footnote, Hunt pointed out that he had two oral interviews with Boyle to provide a firsthand perspective on the development of ultrasound during WWI. In addition, he states that Boyle had read through the material.)

By 1915, Boyle became concerned with the failure to make use of Canadian scientific expertise and, anxious to contribute to the war effort, he wrote to Rutherford in January 1915, offering his services for no payment and asking "why is there no attempt to mobilize Empire scientific effort?" (Wilson 1983). By about May 1915, Arthur Balfour (the bother-in-law of Lord Rayleigh) had become First Lord of the Admiralty and established the Board of Inventions and Research (BIR: also referred to by some as the Board of Intrigue and Revenge), one of whose express purposes was to look at the many thousands of suggestions made to the Admiralty for devices and methods that could shorten the war. ([One of the many suggestions was from Joseph Woodward, a musichall sea lion trainer, who proposed that seals be trained to 
follow the sounds of enemy submarines. This suggestion was actively pursued in the period from November 1916 to mid-1917, during which, well-known scientists with the help of Woodward attempted to train muzzled sea lions to ignore tasty fish and to follow the sounds associated with submarines. In a recent paper, Wilson (2001) relates the history of this ill-founded scheme.]) The Board consisted of four persons under the leadership of Lord Fisher, together with a scientific consulting/advisory panel of 12. Rutherford was made Secretary of the second panel, focused on "submarines, mines, searchlights, wireless telegraphy, and general electrical, electro-magnetic, optical and acoustical subjects" (Campbell 1999). It had become clear at this stage of the war that enemy submarines had become a serious threat and Rutherford threw himself with enthusiasm into this aspect of the work. When news of Rutherford's appointment reached Boyle, he wrote to him on August 17, 1915 , to seek advice as to how he could contribute (Marsden 1956).

Within a few months of his appointment to the BIR, Rutherford had analyzed the challenges that needed to be addressed in submarine detection. In essence, his analysis was based on the laws of physics, through which he identified four potential means of detection. These were the sound emitted, the heat emitted, the electromagnetic disturbance created and their visual characteristics (Wilson 1983). Rutherford's initial work was primarily devoted to the passive detection method in which sounds emitted by a submarine were to be used for identifying and locating its position. In fact, C.P. Ryan (a Naval Officer) and his small group were in the process of developing underwater acoustic microphones at the Hawkcraig Experimental Station, Granton, on the Firth of Forth (Scotland), for the purpose of detecting and signaling between submarines. Rutherford visited the Station in September of 1915 and determined that the group needed much more support in the development of passive detection devices that relied on detecting the acoustic sounds emitted by a submarine. Meanwhile, it appears that Rutherford in his Manchester laboratory was already carrying out some preliminary experiments with quartz (a piezoelectric material), possibly to determine whether it could be useful in detecting and generating sound.

Most of the effort throughout the remainder of 1915 and most of 1916 was devoted to submarine detection by passive means, i.e., by detecting the sounds emitted. But around this time it was realized that active methods had significant potential advantages and that such methods would need a narrow beam that could be directed toward the target. Langevin, in France, appears to have appreciated this and, in July of 1916, an exchange of information with the UK revealed that the French group had conducted successful experiments in which ultrasound was generated by an electrostatic method (the singing condenser) and that signaling over a one-way distance of several kilometers had been demonstrated. Chilowski, who had been working with Langevin, traveled to England to give a first-hand description of these experiments to the BIR. It was at about the same time (September 1916) that Rutherford produced a report describing his own work with piezoelectric crystals for generating high-frequency waves (Wilson 1983).

By April 1916, Boyle had arrived in England at the invitation of the Admiralty and the BIR, probably through Rutherford's influence. According to Hackmann (1984), his first task was to design a towed underwater electric acoustic signaler at Rutherford's Manchester laboratories. After Chilowski's visit, Boyle was assigned the task of replicating some of the experiments performed earlier by Langevin and Chilowski. His first experiments were conducted at the London (South Acton) laboratory of William Duddell and S.G. Brown, where the equipment needed for these investigations was made available. In particular, they had a high-frequency Poulsen arc that was used to excite a singing condenser ultrasound transmitter. It seems that the results were not particularly encouraging, in part because the means for detecting the ultrasound was very inadequate. Toward the end of 1916, communications between Boyle and Rutherford indicated that both were deeply involved in experimental work on piezoelectric devices. For example, Fig. 3 shows a letter with the circuit diagram of a $\mathbf{F 3}$ thermogalvanometer detector for measuring the signal from a piezoelectric device. However, the difficulty of detecting the small signals without the benefit of amplifiers still remained. Very early in the new year of 1917, one communication from Boyle asks whether one of Rutherford's quartz devices could be used both to transmit and receive supersonics (Wilson 1983). Other communications indicate that Boyle was being moved to Parkeston Quay, Harwich, on the southwest coast of England. Langevin visited BIR in March of 1917 and disclosed a number of important technical advances, especially those related to the use of quartz. This was followed by a two-month visit by Boyle to Toulon in the late spring of 1917, to participate in experiments with Langevin on quartz transmitters and receivers. Greatly contributing to the success of these trials was the availability of vacuum tube amplifiers that had been developed by the French as a result of their intensive and successful earlier work to manufacture a much improved version of Le De Forest's Audion three-electrode valve (by the end of the war, the production rate was about 1400 per day (Hackman 1984)). The amplification provided by series connections of these valves enabled ma- 


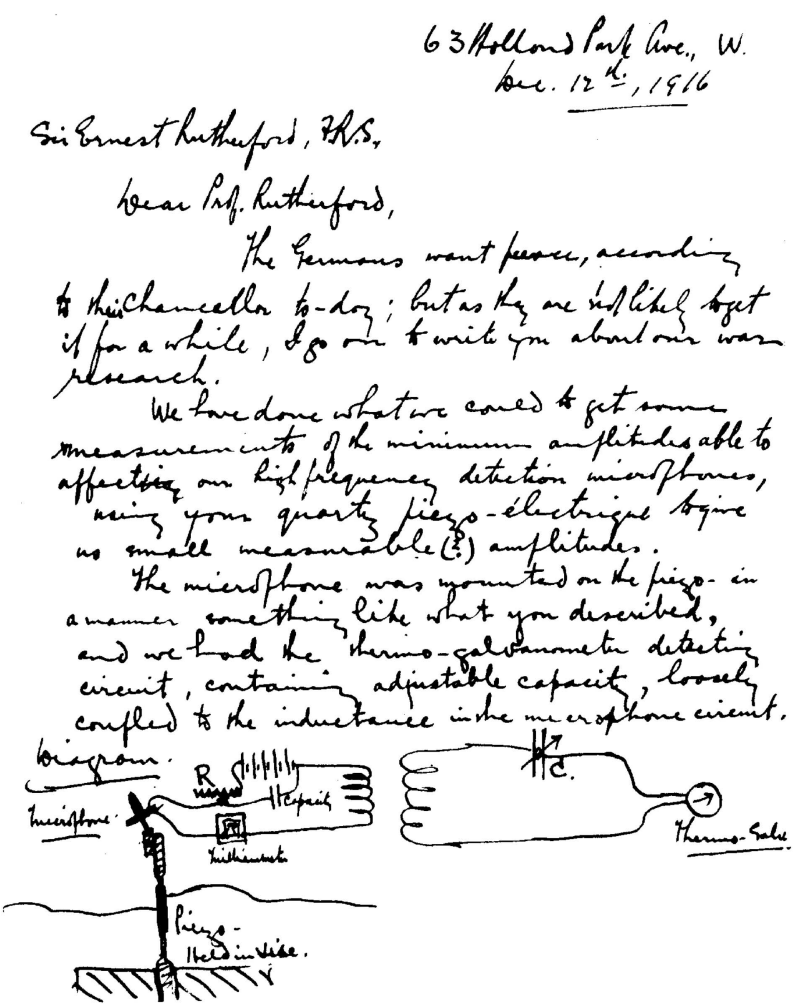

Fig. 3. Letter from Boyle to Rutherford, describing the results of measurements using a piezoelectric source. (Courtesy

McGill University Archives, Montreal (Marsden 1956).) jor improvements to be made in detecting the very weak signals from quartz detectors.

Subsequent to the move to Parkeston Quay, Boyle and his team began development of quartz mosaic transducers and, toward the end of 1917 , had transmitted signals for nearly a mile using a quartz transducer similar to that shown in Fig. 4. According to a report by Eccles in October 1917 (Hackmann 1984), the transducer area was 50 square centimeters and the frequency was 75 $\mathrm{kHz}$. Around the same time, some of the French vacuum tube amplifiers had been acquired, enabling Boyle to achieve much higher receiver sensitivity with his quartzbased receivers. The early transducers were nonresonant, but it was soon realized after the earlier work by Langevin that, to improve the efficiency, both the transmitter and receiver transducers should operate at their resonant frequencies. With the redesigned transducers, Boyle attempted to detect submarines using a shadow method in which the submarine would create a shadow between a transmitted beam and a receiver on the other side. These experiments, which were conducted in December of 1917, were not successful because of spurious reflections from the sea bed. As a result, Boyle concentrated on the echo method and was rewarded in March 1918 with echoes from a submarine at a distance of 500 yards. Around the same time, he realized that the same transducer could be used for both transmission and reception, thereby considerably simplifying the system. It seems that a Morse key was used to interrupt the transmission,
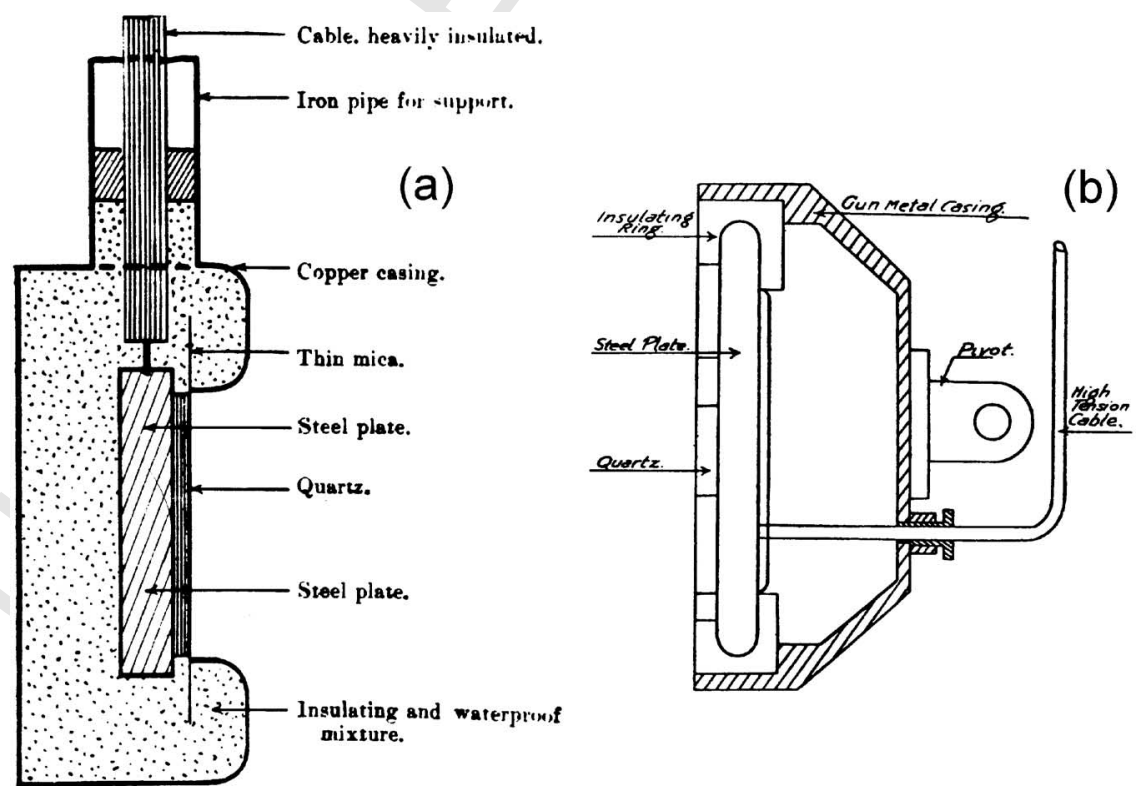

(b)

Fig. 4. Cross-sectional views of two forms of quartz transducer designed by Boyle (late 1917), as recorded in the BIR document 38164/17. Both transducers have a mosaic of quartz elements, thereby obviating the need to use large single crystals, which were in very short supply. (a) Transducer with a mica insulator on the surface. (b) Transducer intended for transmission: the salt water provides electrical contact to the outer quartz surface. 


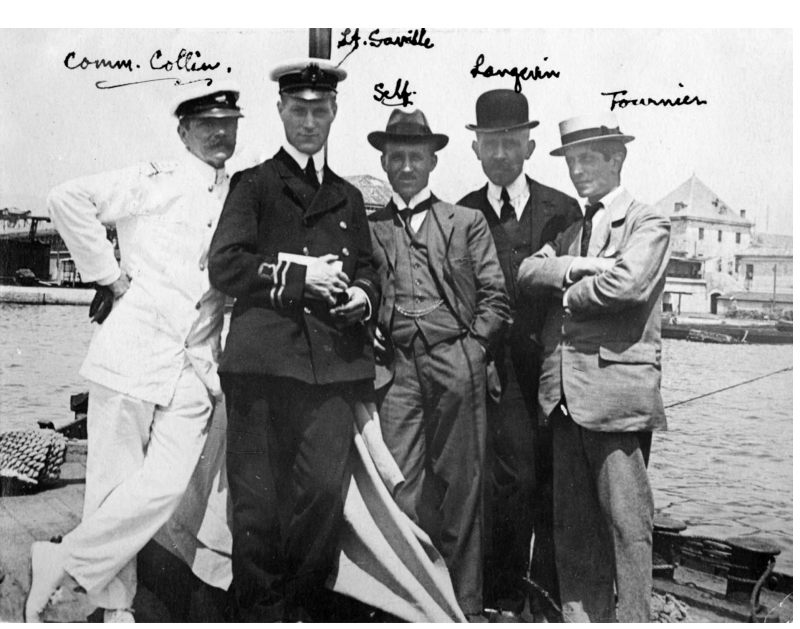

Fig. 5. Late spring or early summer of 1917 at Toulon (France), showing some of the pioneers of ultrasonic range finding. Boyle and Langevin (with the bowler hat) are accompanied by Commander Collier, Lieutenant Saville and Fournier. This copy was originally possessed by Boyle and annotated by him with a note on the back that it was taken in the summer of 1917.

(Courtesy Robert Greenway of Lexington, MA, USA.)

thereby solving the isolation problem that would otherwise be present.

Hackmann (1984) has recounted subsequent development and practical realization of a detection system for installation on Navy ships. He notes that, by June of 1918 , based on preliminary tests, an order for 20 ASDIC sets was placed and technical drawings were prepared for installation in a variety of Naval ships. Hackmann (1984) also notes "Had the war continued for only a few months more \{beyond November 1918\}, the Royal Navy would have had the first asdic sets in service and the skilled operators to man and repair them. It was a fine achievement by Boyle and his team was helped in no small measure by their close co-operation with the French research workers."

During the wartime period in the UK, Boyle traveled frequently between the various research stations. He had at least four trips to France. The first, as noted earlier, was to Toulon in 1917 (Fig. 5), the second and third were in May and June 1918 and the last was in October of 1918 (Hackmann 1984) to attend an Allied conference on supersonic methods for detecting submarines, a conference that was still in progress when the war ended in November.

On April 23, 1919, Boyle wrote (Marsden 1956) to Rutherford from the Admiralty in London, reporting that Dr. Tory had written asking for his decision about returning to the University of Alberta. He told Rutherford "I shall hate leaving Asdics in its full development, but I shall try to do some pure research in it ..." In his concluding report to the Admiralty before returning,
Boyle suggests: "Considering their application in the future to all ships of the Navy and Mercantile Marine, these [ASDIC] results in my opinion warrant the continuation of this work in England on a much larger scale than the merely scientific experimental work we have accomplished so far" (Hackmann 1984).

For his wartime contributions, it would seem that Boyle had been offered a CBE (Order of Commander of the British Empire) by the British government. Rutherford, in writing to Boyle on April 23, 1921, stated (Eve 1939): "I was very pleased to learn that they had offered you a CBE. It is one of the misfortunes of living in such a democratic country that you are unable to sport the insignia of the order.'

\section{ULTRASOUND RESEARCH AT THE UNIVERSITY OF ALBERTA (1919-1929)}

At the urging of Tory, Boyle returned to Alberta in 1919 to resume his appointment as Professor of Physics at the University of Alberta and to develop a research program focused on the fundamental ultrasonic problems that he had encountered while in England. Two years later, in 1921, he was appointed the Dean of the recently established Faculty of Applied Science, a position he used to create a hub of research in Western Canada. During his years at the University of Alberta, he performed many experiments, trained many graduate students and published many papers related to his ultrasound research.

Boyle was likely the first scientist to conduct a detailed study of acoustic cavitation resulting from the passage of ultrasonic waves. In fact, his first research paper since returning to the University of Alberta was entitled "Cavitation in the propagation of sound."[9] Although this work was of a theoretic nature, subsequent publications described experimental observations and noted the continuous formation of bubbles close to an ultrasonic source when it was driven with sufficient power.[27]

Boyle's 1922 paper pointed out the possibility that the amount of sound wave energy transmissible through a liquid could be limited by cavitation.[9] He provided a good physical explanation of the phenomenon as follows. When a medium cannot follow the harmonic vibration of the source, a vacuum or partial vacuum can be created. If the alternating pressure wave exceeds the static pressure, the medium would be under tension at the moment of greatest rarefaction; the tension would result in discontinuities in the medium and formation of bubbles (i.e., cavitation), interrupting the rhythmic character of the wave. The question, according to Boyle, was whether the laws of cavitation would remain valid at high frequencies. Although, at the time of the 1922 
paper, the phenomenon could not be tested experimentally ("unfortunately we have no practical cases where the emission of energy is great enough for this phenomenon of cavitation to intervene"), Boyle's calculations indicated that, in transmission of sound through liquids, cavitation would indeed limit the power of transmission. In the following years, Boyle and Lehmann and, subsequently, Boyle, Taylor and Froman were able to observe and study these effects experimentally.

In a 1923 report on ultrasonics to the Canadian Research Council, Boyle and Lehmann revealed that bubbles could be produced at lower energies in volatile organic liquids (e.g., benzol) compared with water. These bubbles could then be used to indicate positions of nodes of ultrasonic stationary waves, allowing for measurement of wavelength and, hence, velocity.[27] In fact, Boyle used such a technique in several of his experiments. In a 1927 letter to the journal Nature entitled "Ultrasonic Stationary Waves," Boyle discussed using cavitation to visualize stationary waves, allowing for determination of velocity of sound in liquids.[19] In another letter published in Nature, he again wrote about using the formation of bubbles as a tool to measure velocity of sound in tubes.[28]

Boyle and Taylor reported experiments in which they measured the approximate intensity needed to produce cavitation (in gasoline) and found that it was much less than that predicted by theory. Boyle and Froman later repeated these experiments under better conditions. Their results were published in a 1929 paper entitled "Cavitation in the Track of an Ultrasonic Beam."[27] These and other experiments were conducted in his laboratory, which, as shown in Fig. 6, was equipped with a large wooden tank $(4.5 \mathrm{~m} \times 1.5 \mathrm{~m} \times 1.0 \mathrm{~m})$ and also had a side-bay for reflection measurements.

Boyle also conducted a variety of experiments related to transmission and reflection of waves. In several papers, he emphasized the importance of ultrasound as a tool for investigating many problems in physics not possible with light and sound. In [13] he stated: "By making use of ultrasonic oscillations, workable wavelengths of a fraction of a centimeter or a few centimeters can readily be obtained," whereas light waves were too short and ordinary sound waves too long for experimental work. Many experiments were conducted related to transmission and reflection of waves from partitions of varying thickness.[16,24,26,29] Boyle and Lehmann's experiments confirmed Rayleigh's mathematical theory that, at normal incidence on a surface, the reflected wave is maximum when the thickness is a quarter of the wavelength and a minimum when it is half the wavelength.[16]

A number of new methods for detection and visualization of ultrasonic beams were developed and de-

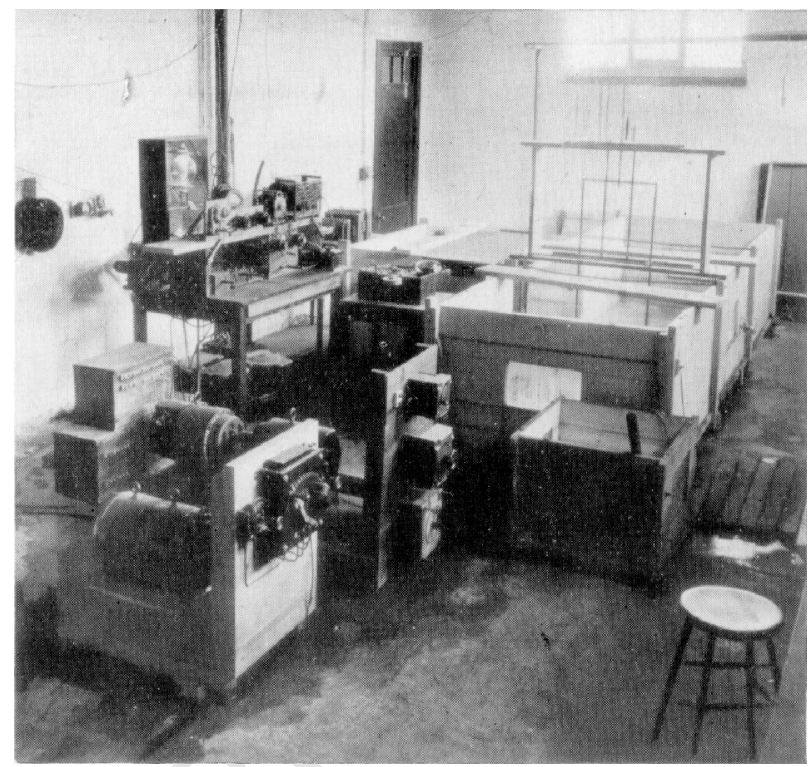

Fig. 6. Boyle's laboratory for experimental ultrasound measurements at the University of Alberta, circa 1928. (Courtesy Hodder Education, from Science Progress 1928-29;23:75-105)

scribed. For example, in 1925, Boyle and Lehmann introduced a new photographic method using "dust figures" to help to visualize the formation of an ultrasonic beam and its energy distribution.[12] The method involved small, light dust particles sprinkled in front of the generator in water. The particles, as they sank, were driven forward by the pressure of the radiation ("majority of them will be jostled from the regions of maximum to the regions of minimum energy densities"). If caught by a tray below the center of the generator, they formed traces of the surfaces of minimum intensity. The dust figures could then be photographed. According to Boyle, "this method, although qualitative only, helps to envisage what takes place in an ultrasonic field close to a generator."[25] Two examples are shown in Fig. 7. In F7 Fig. 7b, the dust figure is shown for a stationary (standing) wave obtained from the interference of opposing wave trains.

Boyle and his colleagues also performed experiments on diffraction and scattering of ultrasonic beams. In a 1925 paper,[13] Boyle, Lehmann and Reid examined the phenomenon of diffraction of ultrasonic waves, analogous to diffraction of light through an aperture. In their experiments, a circular plate with longitudinal oscillations served as the aperture and was immersed in their tank of fresh water. The field was visualized using the "dust figure" method and measured using a torsion pendulum. An example of a diffraction pattern obtained by Boyle and his colleagues using the dust figure method can be seen in Fig. 7a. In this case, a transmitter with a 

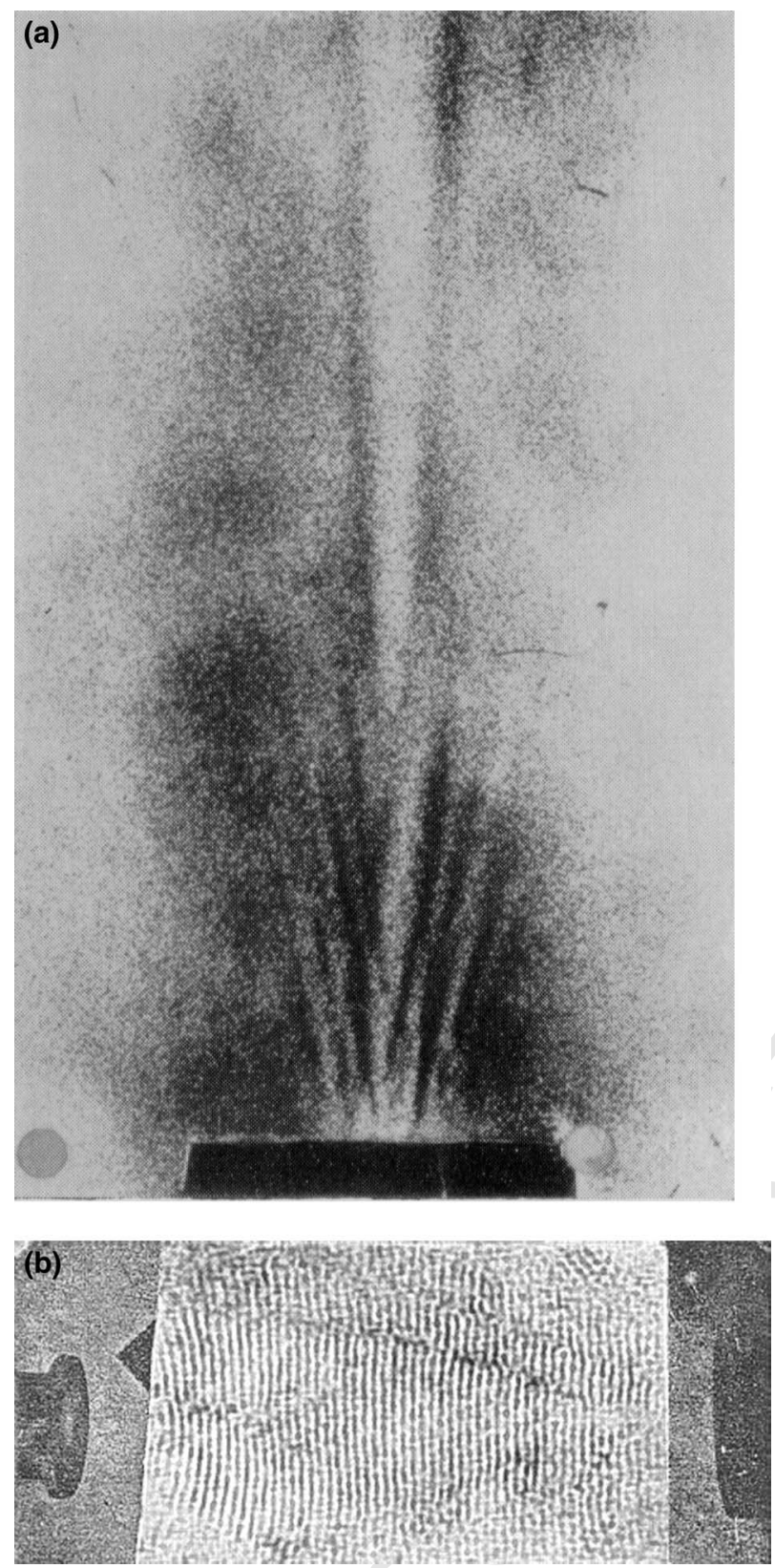

Fig. 7. Dust figures. (a) Progressive waves, from a $15.3-\mathrm{cm}$ diameter transducer excited at $178 \mathrm{kHz}$. This clearly shows the effects of diffraction. (b) Stationary waves produced by the interference of two opposing wave trains produced by two transmitting transducers $(96 \mathrm{kHz}), 60 \mathrm{~cm}$ apart. (Courtesy Hodder Education, from Science Progress 1928-29;23:75-105.)

diameter of $15.3 \mathrm{~cm}$, operating at a frequency of 178000 $\mathrm{Hz}$, was used. The method provided direct visualization of ultrasonic field, including the effects of diffraction, and shows the manner in which the primary ultrasonic beam was formed.

Using a torsion pendulum, in which the radiation pressure caused a torque to be produced, Boyle and his colleagues also performed measurements of the intensity in the axial and radial directions of the ultrasonic radiation and compared them with theoretic predictions from optics.[13] By applying a counter torque to the quartz fiber so that the vane was restored to its equilibrium position, the field intensity could be determined. The results, as shown in Fig. 8, were compared with formulae $\mathbf{F 8}$ given by Verdet for "diffraction of train of plane waves of monochromatic light passing through a small circular opening." Boyle points out that, in the case of ultrasonic beams at a considerable number of wavelengths away from the transmitter, Verdet's formula should hold true in the ideal case.

Another practical and important problem at the time was the detection of submerged objects at sea, and this provided the impetus for another branch of Boyle's research program. The objects of particular interest were the steel of ships' hulls, rocks of shorelines, submerged rocks and icebergs. Boyle and his students performed experiments to determine the reflection from many of the materials of practical importance. The experiments indicated that the relative intensities reflected off granite and ice were in the ratio of about 3:1.[18] Boyle was especially interested in examining the possibility of application of ultrasound for detection of icebergs. In fact, during 1924, Boyle and Reid took a trip on a steamer of the Department of Marine and Fisheries of Canada through the Gulf of St. Lawrence and Straits of Belle Isle. Their goal was to find the range at which an iceberg could be detected in comparison with the range for a steel ship or rocky shore and the difficulties that might be encountered. Although, according to Boyle, "the season was an unfortunate one ... for very little ice was encountered,"[17] the experiments showed that the range of detection of an iceberg in deep water was somewhat greater than expected, about one quarter of the range of a steel ship or rocky shore.[25] However, in shallow water, they found that the bottom and surface echo would mask the echo from the ice.

One important question that Boyle and his colleagues addressed in some of their papers $[14,20,23]$ was the question as to whether the speed of sound depended on the frequency of the ultrasound waves. As we now know, the changes are very small in most fluids and are intimately related to the attenuation through the Kramers-Kronig relations. Boyle concluded that the changes in speed with frequency, if they existed, were beyond the accuracy of their experimental measurement methods.

Finally, it should be noted that Boyle prepared what was the first extensive review of the new field of ultrasound.[25] It was published in 1928 and, as might be expected, contained a good deal of what he had published earlier since his first article on the subject in 1922. $\mathrm{He}$ discussed the emergence of the field of "modern 


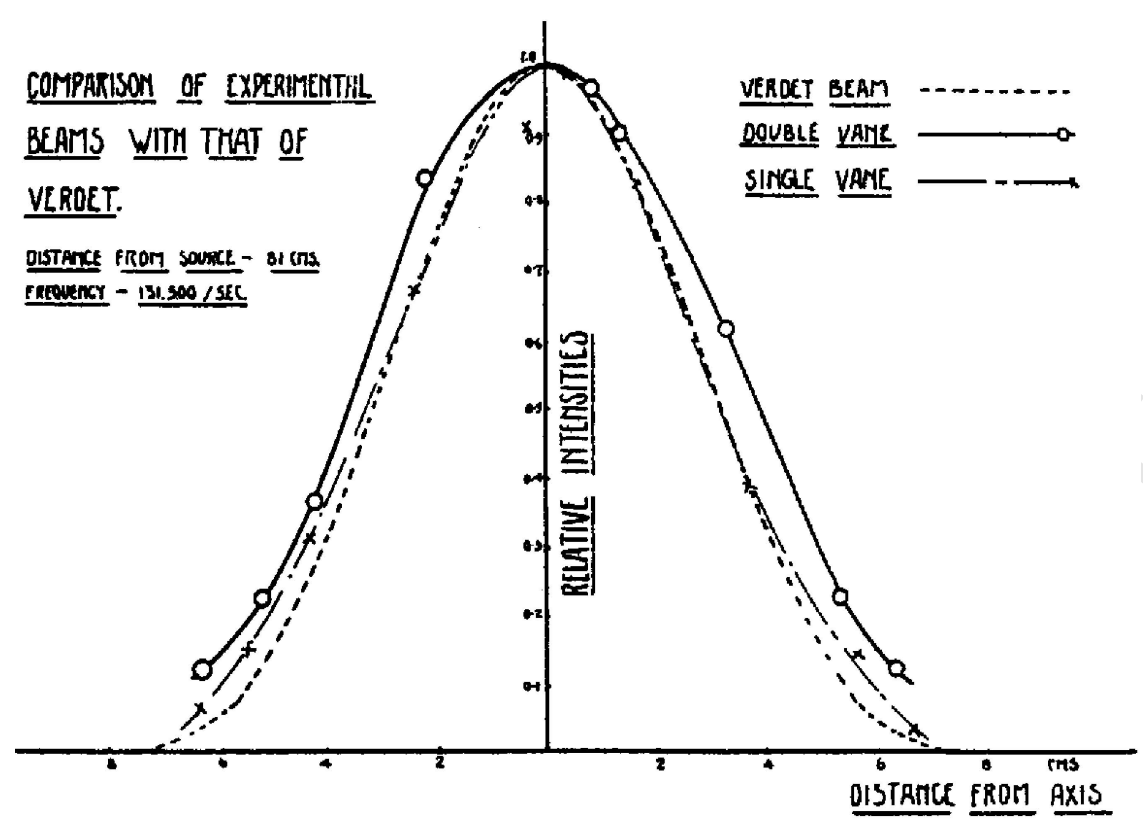

Fig. 8. Comparison of experimentally-measured field profile in the radial direction at a distance of $81 \mathrm{~cm}$ from a $15.3-\mathrm{cm}$ transducer excited at its resonant frequency of $131 \mathrm{kHz}$, with that calculated. The intensity measurements were performed by using the radiation pressure exerted on a torsion pendulum. (Courtesy Royal Society of Canada, from Royal Soc Can Trans 1925;19:167-196.)

ultrasonics" dating back to the 1912 sinking of the Titanic and the ensuing proposals to employ "echoes of high-pitched acoustic waves". He acknowledged the pioneering work of Langevin and the impact of his experiments, some of which Boyle himself assisted with. He discussed the theory of ultrasonic beams and diffraction, piezoelectricity as a source of ultrasound, the prevalent ultrasound research methods and tools and various applications.

During the time he spent in Edmonton, a number of honors came his way. In 1921, he was elected to the Royal Society of Canada and served terms as Vice President (1923-1924) and President (1924-1925) of the Mathematics and Physics section. He served on the Advisory Board for the Royal Military College, Kingston, from 1928 to 1929. He was also active in the Association of Professional Engineers of Alberta, serving as President for a 1-y term.

\section{NATIONAL RESEARCH COUNCIL YEARS (1929-1948)}

By 1924, Dr. H.M. Tory ([ In 1947, on the death of Henry Marshall Tory, Boyle wrote a lengthy biographic sketch of this great Canadian who had founded so many academic and research institutions (Boyle 1947).]) had left the University of Alberta to become the founding President of the National Research Council of Canada. According to Middleton (1979), Boyle was in Europe during the summer of 1928 and it seems that Tory had provided him with the expenses needed to visit various laboratories in France, Germany and England. In view of this, it seems likely that preliminary discussions had already taken place concerning the possibility of an appointment in the newly established National Research Council. In March 1929, Tory reported that four professional divisions had been created. The appointment of Boyle to head the Physics Division was approved by the NRC Board without dissention and Boyle arrived in August 1929 to an organization that was still in the formative stage and which lacked a permanent site. It was soon after this that Parkin was appointed to take charge of aeronautical research and to be Assistant Director of Physics.

One of the immediate tasks facing Boyle was that of hiring staff. In this, it was decided to hire promising young individuals fairly fresh out of graduate school, rather than to entice more experienced graduates from academia (Middleton 1979). One of those hired in 1931 was George S. Field, who was formerly one of Boyle's research graduate students in Edmonton. He was given charge of research in acoustics and ultrasound, which was shortly to become a section within the Physics Department. Boyle collaborated with Field in his research and was a coauthor on two papers [32,33] published in 1932. But this seems to be the last time that he was actively to be involved in research: shortage of funds 
Because a freeze was placed on all hiring in the

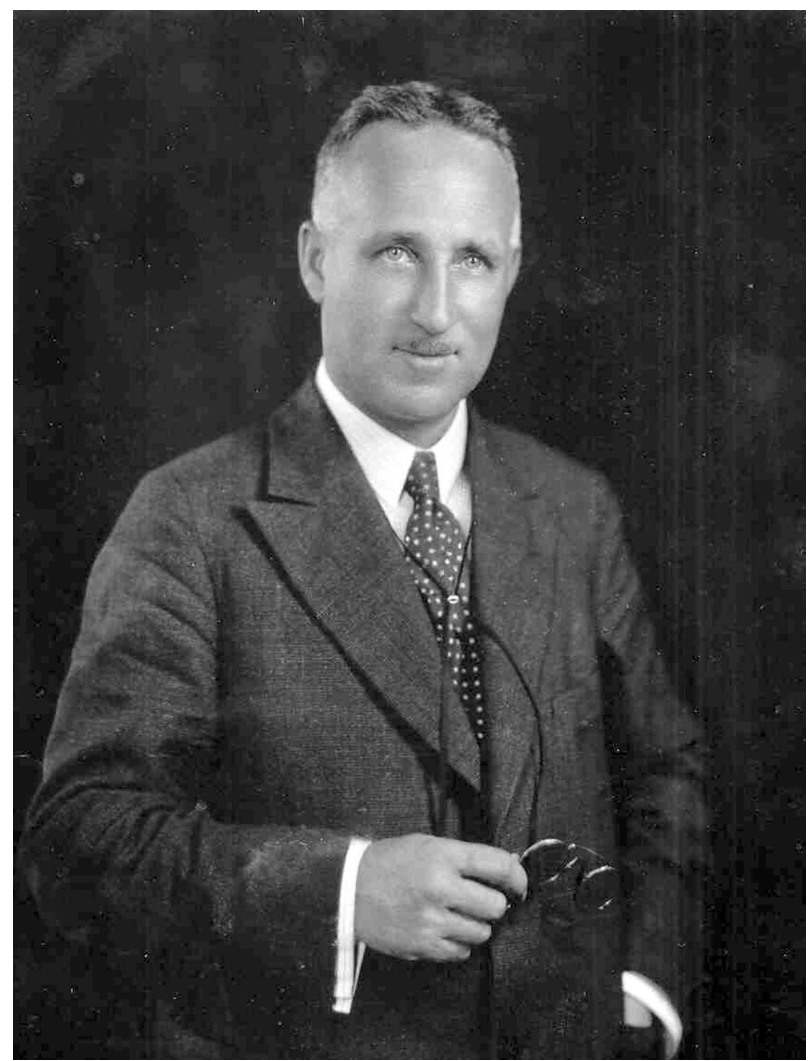

Fig. 9. Formal portrait of Boyle, probably taken in Montreal, around the time he was in his late 40s (i.e.,1930s). (Courtesy Frederick Boyle of Springvale, ME, USA, a nephew of Dr. R.W. Boyle.)

during the early stages of the depression, responsibilities in building up what had now (1931) become the Division of Physics and Engineering, together with administrative duties, seemed fully to occupy his time (see Fig. 9). In 1932, the new laboratory and headquarters building on Sussex Drive (Ottawa) was opened and the Division moved into a new home. The following year, the University of Alberta, to which Boyle had contributed so much in terms of building new departments and establishing an outstanding research program, offered him an honorary LLD. However, he was unable to be present at either the 1933 or 1934 Convocations and as a result was unable to receive it. ([ It is clear from the correspondence for 1933 and 1934 between Boyle and the President of the University of Alberta that it was the University's policy not to award honorary degrees in absentia. The report in the Edmonton Journal for May 16, 1933, that Boyle had been awarded an honorary LLD (in absentia) appears to be incorrect. Several subsequent listings of Boyle's achievements incorrectly include the LLD with his other degrees.]) It was around this time that he was also elected a Fellow of the Acoustical Society of America and made a Fellow of the American Physics Society. public service, no further expansion of the Division was possible in the early 1930s. Two years later (December 12, 1934), Boyle wrote to Rutherford (Marsden 1956) complaining of the difficulties he faced. But more were to come a few months later, when Tory resigned as President of the NRC and General McNaughton was appointed President in early June 1935. As second-incommand to Tory, Boyle had firm expectations that he would be appointed President on Tory's retirement. He was acutely disappointed over what turned out to be a political decision made by Prime Minister R.B. Bennett. In a long typewritten letter dated July 13, 1934 (Marsden 1956), he poured out his frustration to his friend and mentor, Lord Rutherford. It would seem that Boyle had a great deal of difficulty in overcoming this setback, which may have caused difficulties for his Division. Around the same time, mechanical and aeronautical engineering became separate Divisions and, as a result, Boyle's Division was renamed Physics and Electrical Engineering. Also, around the same time, Boyle served on the Advisory Board of the Royal Military College in Kingston, Ontario, serving as its chair for 1935, 1936 and 1937.

By the time WWII had started, Boyle's Division consisted of 26 physicists and electrical engineers and 37 technical assistants. However, the emphasis was on problems directly concerned with the war effort and, as a result, the Division of Physics and Electrical Engineering was greatly expanded. Early in the war, Boyle was awarded the Flavelle Medal of the Royal Society of Canada (RSC 2006) in 1940, primarily for his pioneering contribution in WWI to submarine detection methods. His work in this new wartime period was quite different in that he was now responsible for work in a wide variety of areas directed toward problems of war-time interest. By the end of the war, much of this research and development was either terminated or transferred to the newly established (1947) Defense Research Board of Canada. By 1946, the Physics part of Boyle's Division was considered to be adrift (Middleton 1979) and the President decided to seek an internationally respected individual with a new program of research. This was to be Gerhard Hertzberg (1971 Chemistry Nobel Prize), who was appointed as Principal Research Officer and arrived from the University of Chicago in 1948. Early in 1948, an Order in Council created a new Division of Electrical Engineering and Radio, leaving Boyle as Director of Physics. On his 65th birthday (October 2, 1948), Boyle retired and, at a dinner of his friends and colleagues, was warmly toasted and given a gold watch and chain. Hertzberg was appointed Director of Physics and assumed his new duties at the start of 1949. 


\section{THE FINAL PERIOD (1948-1955)}

Boyle spent much of his retirement years traveling to many continents, enjoying the company of friends and relations and fishing. He was generally considered to be in good heath, but while on tour in Europe died with little warning in London on April 18, 1955. A funeral service was held at Golders Green Crematorium in London and his ashes were buried in Woodlawn Cemetery, Everett, Massachusetts, next to the graves of his parents. Although he never married, he had many relations and friends, some of whom were to benefit from his wise investments. In his will, he specified two scholarships to the United Church School in Carbonear (where he was born) and two undergraduate scholarships at Memorial University, Newfoundland, one to a female student in memory of his mother, and the other to a male student in memory of his father.

Subsequent to his death, there were many obituaries (e.g., Shaw 1955; Keys 1955a; Anon 1955), the most detailed of which was by David A. Keys (Keys 1955b). ([David Keys (a Canadian) had worked for the Admiralty in England towards the end of WWI doing research and development on the detection of explosions. He had experimented with a quartz piezoelectric detector and appears to have first met Boyle just after the end of the war (Keys 2001). Subsequently, he became the McDonald Professor of Physics at McGill.])

\section{SCIENTIFIC PUBLICATIONS OF R.W. BOYLE}

[1] Boyle RW. Absorption of radioactive emanations by charcoal [abstract]. Am Electrochem Soc Trans 1908; 13:429.

[2] Boyle RW. Absorption of radio-active emanations by charcoal. J Phys Chem 1908;12:484-506.

[3] Boyle RW. Absorption and adsorption with reference to the radio-active emanations. Bulletin of the Macdonald Physics Building, McGill University, No 1. pp.1 to 59, April 1910.

[4] Boyle RW. Absorption and adsorption with reference to the radio-active emanations. $\mathrm{PhD}$ thesis $\mathrm{Su}$ pervisors: John Cox, H.T. Barnes and A.S. Eve), McGill University, 1909.

[5] Boyle RW. Volatilisation of radium emanation at low temperature. Phil Mag 1910;20:955-966.

[6] Boyle RW. Solubility of radio-active emanations in liquids. Roy Soc Canada Trans (Sect. 3) 1910;3:7580.

[7] Boyle RW. Behaviour of radium emanation at low temperature. Phil Mag 1911;21:722-732.
[8] Boyle RW. Solubility of radium emanation. Application of Henry's law at low temperature. Phil Mag 1911;22:840-854.

[9] Boyle RW. Cavitation in the propagation of sound. Roy Soc Canada Trans (Sect. 3) 1922;16:157-161.

[10] Boyle RW. Compressional waves in metals produced by impact. Roy Soc Canada Trans (Sect. 3) 1922;16:293-299.

[11] Boyle RW, Morgan FC, Lehmann JF. Audible sonic beats from inaudible sources. Roy Soc Canada Trans (Sect. 3) 1923;17:141-145.

[12] Boyle RW, Lehmann JF. A new photographic method to demonstrate the interference of longitudinal wave trains: The velocity of high frequency sound in a liquid. Roy Soc Canada Trans (Sect. 3) 1925;19:159-165.

[13] Boyle RW, Lehmann JF, Reid CD. Visualization and energy survey of a high frequency diffraction beam. Roy Soc Canada Trans (Sect. 3) 1925;19: 167-196.

[14] Boyle RW, Taylor GB. The small effect of high frequency on the velocity of longitudinal waves in liquids. Roy Soc Canada Trans (Sect. 3) 1925;19: 197-203.

[15] Boyle RW, Taylor GB. Cavitation in the track of an ultrasonic beam. Phys Rev 1926;27:518, (abstract of paper presented at meeting, Feb. 1926)

[16] Boyle RW, Lehmann JF. The relation between the thickness of a partition in a medium and its reflection of sound waves - by the ultrasonic method. Phys Rev 1926;27:518, (abstract of paper presented at meeting, Feb. 1926).

[17] Boyle RW, Reid CD. Practical experiments on the detection of icebergs and on sounding by means of an ultra-sonic beam. Roy Soc Canada Trans (Sect. 3) 1926;20:233-243.

[18] Boyle RW, Taylor GB. Reflecting powers of various materials for ultrasonic waves. Roy Soc Canada Trans (Sect. 3) 1926;20:245-257.

[19] Boyle RW. Ultrasonic stationary waves. Nature 1927;120:476-477.

[20] Boyle RW, Taylor GB. Constancy of ultrasonic velocity in liquids with increasing frequency. Roy Soc Canada Trans (Sect. 3) 1927;21:79-83.

[21] Boyle RW, Lehmann JF. Passage of acoustic waves through materials. Roy Soc Canada Trans (Sect. 3) 1927;21:115-125.

[22] Boyle RW, Rawlinson WF. Theoretical notes on the passage of sound through contiguous media. Roy Soc Canada Trans (Sect. 3) 1928;22:55-68.

[23] Boyle RW, Lehmann JF, Morgan SC. Some measurement of ultrasonic velocities in liquids. Roy Soc Canada Trans (Sect. 3) 1928;22:371-378. 
[24] Boyle RW, Transmission of sonic and ultrasonic with valuable information. In addition, we are grateful for the assiswaves through partitions. Nature. Jan 14, 1928;121: 55-56.

[25] Boyle RW, Ultrasonics. Science Progress 1928;23: 75-105.

[26] Boyle RW, Froman DK. Reflection of sound energy and thickness of plate reflector - Ultrasonic method. Can J Res 1929;1:405-424.

[27] Boyle RW, Taylor GB, Froman DK. Cavitation in the track of an ultrasonic beam, Roy Soc Canada Trans (Sect. 3) 1929;23:187-198, discussion 199201.

[28] Boyle RW, Froman D. Velocity of sound in tubes: ultra-sonic method. Nature 1930;126:602-603.

[29] Boyle RW, Sproule DO. Transmission of sound energy and thickness of plate transmitter at normal incidence - ultrasonic method. Can J Res 1930;2: 3-12.

[30] Boyle RW, Lehmann JF. Diffractive reflection and scattering of ultrasonic waves: their influence on torsion-pendulum measurements of sound intensity. Can J Res 1930;3:491-509.

[31] Boyle RW, Sproule DO. Velocity of longitudinal vibration in solid rods (ultrasonic method), with special reference to the elasticity of ice. Can J Res 1931;5:601-618.

[32] Boyle RW, Froman DK, Field GS. Ultrasonic dispersion and selective absorption in liquids. Part I. Can J Res 1932;6:102-118.

[33] Field GS, Boyle RW. Ultrasonic dispersion and selective absorption in liquids. Part 2. Can J Res 1932;6:192-202.

Acknowledgements - We especially thank Elinor and Robert Greenway of Lexington, MA, USA, Frederick Boyle of Springvale, ME, USA, Bert Parsons of Carbonear Newfoundland, Dr. John A. Campbell of the University of Canterbury, New Zealand and Sarah Power, previously studying at Memorial University, Newfoundland. They all provided us tance and copies of documents provided by the Archivists from McGill University (Richard Virr), the National Research Council of Canada (Steven LeClair), Royal Military College, Kingston (Ross Mckenzie) and University of Alberta (Bryan Corbett). Finally, we acknowledge financial support from the Natural Sciences and Engineering Research Council of Canada.

\section{REFERENCES}

Anon. Noted Scientist Dr R. Boyle Dies. Edmonton J, 28th April, 1955. Badash L, Rutherford and Boltwood, Letters on Radioactivity. New Haven, CT: Yale University Press; 1969.

Boyle RW. Henry Marshall Tory: 1864-1947. Proc Trans Roy Soc Can 1947;41:136-147.

Campbell J. Rutherford, Scientist Supreme. Christchurch, New Zealand: AAS Publications; 1999.

Eve AS. Rutherford. Cambridge: Cambridge University Press; 1939.

Hackmann WD. Seek and Strike: Sonar Anti-submarine Warfare and the Royal Navy 1914-1954. London: Her Majesty's Stationary Office, 1984.

Hunt FV. Electroacoustics: The analysis of transduction and its historical background. Cambridge, MA: Harvard Univ Press; 1954.

Keys DA. Dr RW Boyle [obituary]. Nature 1955a;175:1020.

Keys DA. Robert William Boyle 1883-1955. Proc Trans Royal Soc Can 1955b;49:63-67.

Keys DA. Autobiography, David Arnold Keys, 1890-1977, early years, 1890-1924. Ottawa, Ontario, Canada: J. Keys; 2001.

Marsden E, editor. Correspondence of Lord Rutherford of Nelson, vol.

3. Edited for the Rutherford Memorial Committee of the Royal Society, London. Montreal, Ontario, Canada: McGill University Arch; 1956.

Middleton WEK. Physics at the National Research Council of Canada, 1929-1952. Waterloo, Ontario, Canada: Wilfred Laurier Press; 1979.

Royal Society of Canada. Flavell Medal Citations, 2006. Available at: http://www.rsc.ca/index.php?page = citations_flavelle\&lang_id = 1\&page_id=159\#TOC45.

Rutherford E. Radioactive substances and their reactions. Cambridge: Cambridge University Press; 1913.

Shaw A.N. Recollections of Robert William Boyle, 1883-1955. Phys Can 1955;10(4):21-28.

Wilson DAH. Sea lions, greasepaint and the U-boat threat: Admiralty scientists turn to the music hall in 1916. Notes Records Roy Soc London 2001;55:425-455.

Wilson D. Rutherford, simple genius. London: Hodder and Stroughton; 1983. 
JOBNAME: AUTHOR QUERIES PAGE: 1 SESS: 1 OUTPUT: Sat Sep 9 14:14:27 2006

/tapraid3/z2y-umb/z2y-umb/z2y01106/z2y7820d06z

\section{AUTHOR QUERIES}

